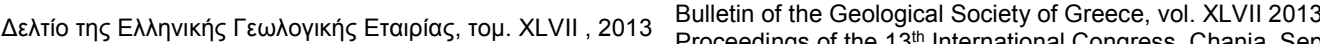

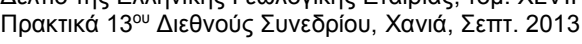
2013

\title{
THE TECTONO - STRATIGRAPHIC EVOLUTION OF EASTERN MEDITERRANEAN WITH EMPHASIS ON HERODOTUS BASIN PROSPECTIVITY FOR THE DEVELOPMENT OF HYDROCARBON FIELDS
}

\author{
Elia C. ${ }^{1}$, Konstantopoulos P. ${ }^{1}$, Maravelis A. ${ }^{2}$ and Zelilidis A. ${ }^{1}$ \\ ${ }^{1}$ University of Patras, Department of Geology, Laboratory of Sedimentology, 26504 Patras, \\ Greece,A.Zelilidis@upatras.gr \\ ${ }^{2}$ School of Environmental and Life Sciences, University of Newcastle, Callaghan 2308 NSW, Aus- \\ tralia,Angelos.Maravelis@newcastle.edu.au
}

\begin{abstract}
The eastern part of the Mediterranean Sea is of great geological interest. One of the main interesting topics is the genesis and the development of hydrocarbon fields in the area. The analysis of the palaeogeographic evolution of two major basins in eastern Mediterranean Sea, such as Levantine basin and Herodotus basin, shows the same evolution and accommodate the same sediment types. Also, the presence of the Eratosthenes Continental Block (E.C.B.) and the Nile cone, have their own role in the development of the basins and the wider Eastern Mediterranean region. With the help of seismic data, petroleum geology, the evolution of both basins and other geological structures of the region, we can compare the two basins. From the comparison we concluded that Herodotus basin hosts at least the same amount of gas and oil as the Levantine basin.
\end{abstract}

Key words: Levantine basin, Herodotus abyssal plain, hydrocarbons, eastern Mediterranean.

\section{Пєрí $\eta \Psi \psi \eta$}

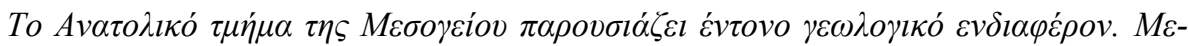

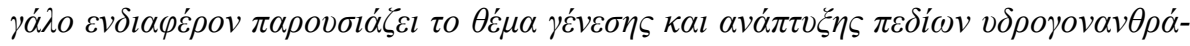

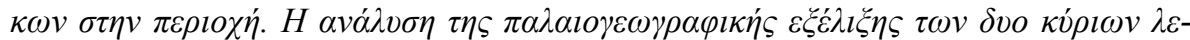

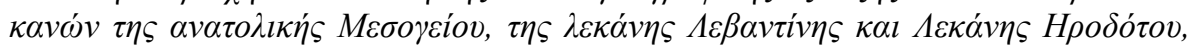

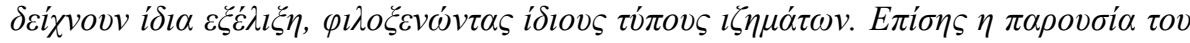

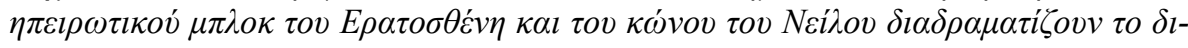

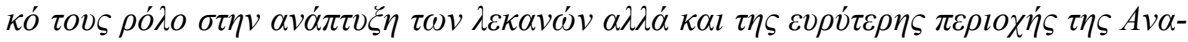

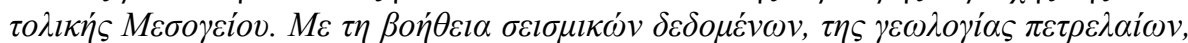

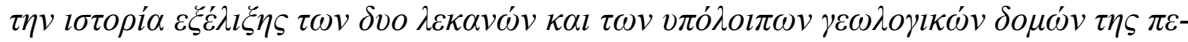

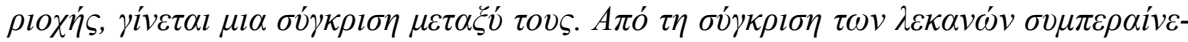

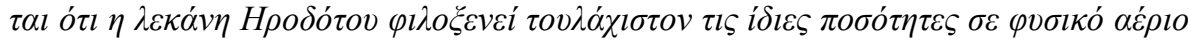

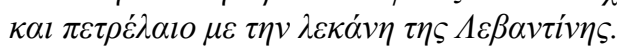

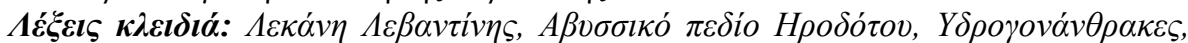

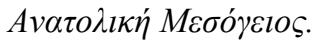




\section{Introduction}

The hydrocarbons in order to produced in high concentrations and can be regarded as economically exploitable, should be kept the following requirements: existence of source rock, migration conditions, existence of reservoir, seal, and trap. The source rocks are fine sediments rich in organic material and which contain the precursors to hydrocarbons, such that the type and quality of expelled hydrocarbon can be assessed. The organic material in order to generate hydrocarbons must be buried in such depths as far as the temperature is between $90^{\circ}-120^{\circ} \mathrm{C}$. The reservoir is a porous and permeable rock that hosts the hydrocarbon reserves. Analysis of reservoir at the simplest level requires an assessment of their porosity, in order to calculate the volume of hydrocarbons and their permeability in order to calculate how easily the hydrocarbons will flow out of them. The seal rock is a unit with low permeability that impedes the escape of hydrocarbons from the reservoir rock. Common seals include evaporates, chalks and shales. Analysis of seals involves assessment of their thickness and extent; such their effectiveness can be quantified. The trap is the stratigraphic or structural feature that ensures the juxtaposition of reservoir and seal such that hydrocarbons remain trapped in the subsurface, rather than escaping and being lost. Finally, careful studies of migration on how hydrocarbons move from source to reservoir and help quantify the source of hydrocarbons in a particular area.

In this paper we analyse the above requirements in the Levantine basin and compare them with Herodotus basin.

\section{Geological Setting}

The Levantine basin is located SE of Cyprus in eastern Mediterranean Sea (Figure 1). It is a foreland basin at the southern end of the front of the Alpine deformation zone, in the zone of interaction between the tectonic plates of Africa, Arabia and Anatolia (Vidal et al., 2000). The basin formed in Middle Miocene as a result of subduction of African tectonic plate under Eurasia. It has an average length $\sim 325 \mathrm{~km}$, an average width $\sim 155 \mathrm{~km}$ and water depth over $2 \mathrm{~km}$. It covers an area of $\sim 50.375 \mathrm{~km}^{2}$. It is bounded to the north from Larnaca thrust zone, to the northwest from Eratosthenes continental block. The Nile cone and the eastern margin of Mediterranean are the southwest and east margins respectively. The basin contains Mesozoic and Cenozoic sequences with thickness up to $14 \mathrm{~km}$. The basin has a complex structure due to compression and extension regime that produced movement of tectonic plates and tectonic gravity processes (Roberts \& Peace, 2007).

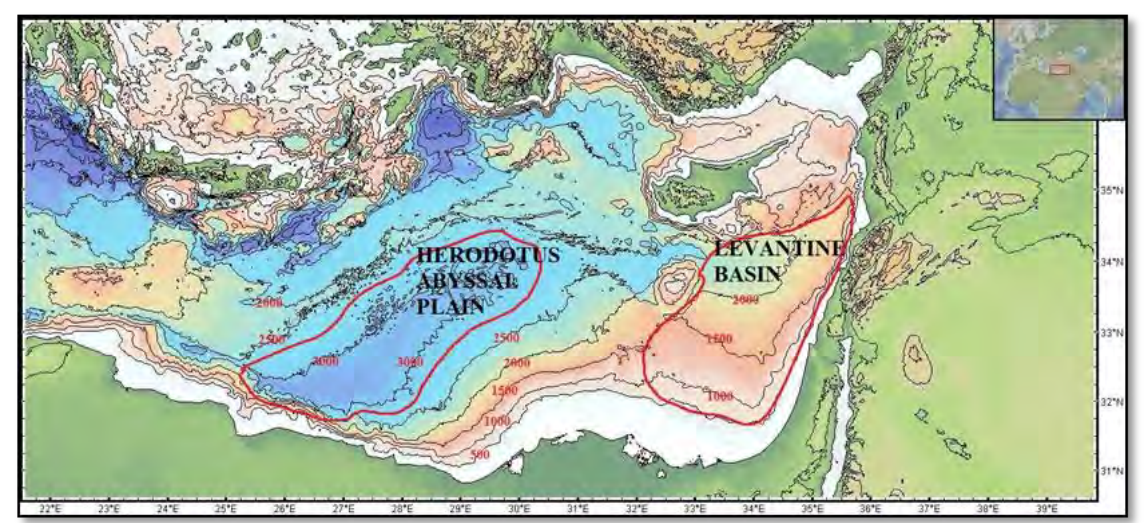

Figure 1 - Bathymetrical map which shows the two basins. NE of Cyprus is the Levantine basin and NW of Cyprus the Herodotus abyssal plain. (Geomap).

Te Herodotus abyssal plain is located SW of Cyprus (Figure 1). The abyssal plain also formed in Middle Miocene as a result of subduction of African tectonic plate under Eurasia. It is a deep basin 
with water depth over $3 \mathrm{~km}$. It has an average length $\sim 450 \mathrm{~km}$ and an average width $\sim 255 \mathrm{~km}$. It covers an area of $\sim 113,000 \mathrm{~km}^{2}$, which is two times bigger than the Levantine basin. On the north is bounded from the Mediterranean ridge, from the African (Libyan/Egyptian) continental slope on the SW and from the Anatolian rise on the NE. The Herodotus basin also contains Mesozoic and Cenozoic sediments up to $15 \mathrm{~km}$ in thickness (Montadert et al., 2009). The size of the basin is reduced during time as the Nile cone proceeds and progrades into the basin. As a result the sediments accreted to the Mediterranean ridge.

\section{Stratigraphy}

\subsection{Herodotus Basin}

The Herodotus basin as mentioned above is composed of clastic sediments with a thickness up to $15 \mathrm{~km}$ (Figure 2). The bedrock of the basin is oceanic crust of Triassic age. The sediments from bottom to top are divided into: a) Mesozoic and Paleogene sediments, b) pre-Messinian sediments (Miocene), c) Messinian evaporites and d) Plio - Quaternary sediments.

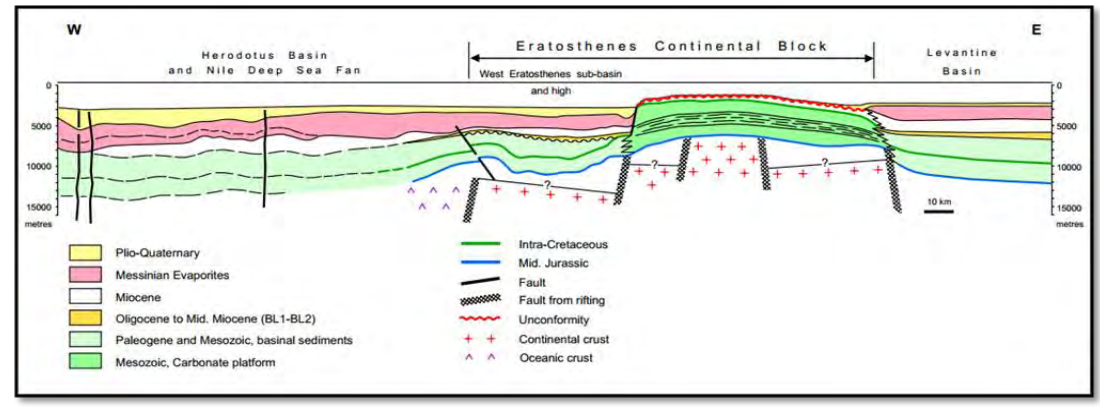

Figure 2 - Stratigraphic cross section of the Herodotus basin and Eratosthenes continental block (Montadert \& Nicolaides, 2010).

\subsubsection{Pre-Messinian Sediments}

These sediments have a thickness greater than $7.5 \mathrm{~km}$ and are divided into seven lithotypes (Figure 2). Calcarenites (Aquitanian) siltstones (Burdigalian), calcareous siltstones (Burdigalian-Langhian), fossiliferous micrites (Serravallian), sapropels (Tortonian), grated biomicrites (TortonianMessinian), bio-arenites (Tortonian-Messinian).

\subsubsection{Messinian Evaporites}

The Messinian evaporites have thickness many times more than $2.5 \mathrm{~km}$ (Figure 2). They were deposited by the closure of Gibraltar so that no water enters from the Atlantic Ocean to the Mediterranean, resulting intense evaporation, and the deposition of halite, gypsum and anydrite in the Mediterranean. The water level fell $3-5 \mathrm{~km}$ in Mediterranean. The structure of the basin is characterized from domes which can form either by syn-depositional folding or diapirism. From magnetic measurements made in the region appear to not be magmatic origin as there are no magnetic anomalies related to the domes. In contrast, sedimentary diapirism indicated by the concentration of domes in a small area of the deepest parts of the basin. The sedimentary diapirs caused by mud or evaporites movement. In gravity measurements made in similar blocks close to this area, show steep negative anomalies Bouguer and show that under these there is a low density material. This material shows evaporitic composition despite mud.

\subsubsection{Plio - Quaternary Sediments}

The Plio - Quaternary deposits consist of sediments rich in carbonate material deposited in the open sea, with plenty of pelagic organisms and benthic fauna. These deposits are brown to black, laminated, rich in organic material sapropels and sand turbidites. The turbidites were divided into

XLVII, No $3-1972$ 
three types, type A and type B and C also debris flow (Figure 3 and 4) according to their source. The types differ in composition and thickness. Finally, they were detected 12 layers of sapropel (Figure 5) rich in organic material, laminated, deposited in anaerobic, deep waters in Quaternary. (Hilgen, 1991; Kempler et al., 1996).

The Type A turbitides (Figures 3 and 4) are rich in smectite which means that the source of this type is the Nile cone because the sediments of the Nile are rich in smectite. They are also rich in organic material. Their thickness range from $15 \mathrm{~cm}$ to $750 \mathrm{~cm}$ (Reeder et al., 2000) and their age range from Middle Pleistocene to Holocene. The transportation from the Nile cone in the basin, made by channels that favor the transport by turbitiditic mud flows. The Type B turbitides (Figure 3 and 4) are richer in carbonates, ranging from $36 \%$ to $84,5 \%$, and that shows that the source of these turbitides is the African continental slope. The transport is done through submarine canyons. Their age is Upper Pleistocene. The most noticeable layer of this type turbidite is called "beta" by the Greek letter ( $\beta$ ). The turbidite sequence ' $\beta$ "' reaches $7 \mathrm{~m}$. in thickness. Finally, their thickness range from 6-1.570 cm (Reeder et al., 2000). The Type C turbitides (Figure 4) derived from the Anatolian rise and are directed towards the east and northeast parts of the basin. Finally, the debris flows (Figure 3 and 4) derived from the Mediterranean ridge and they are limited in the northern part of the basin (e.g. Stow \& Piper, 1984; Stow et al., 1996; Cita et al., 1984a; Lucchi \& Camerlenghi, 1993).

\subsection{Levantine Basin}

The Levantine basin is composed of clastic sediments with a thickness of $14 \mathrm{~km}$ (Figure 5). The bedrock of the basin of Triassic age is not clear whether it is oceanic or continental crust. The sediments from bottom to top are divided into: a) Triassic section, composed by ten depositional cycles, b) Jurassic section, composed by seven depositional cycles, c) Cretaceous section, composed by eight depositional cycles, d) Tertiary section, composed by eleven depositional cycles. The types of the sediments are referring in figure 5 .

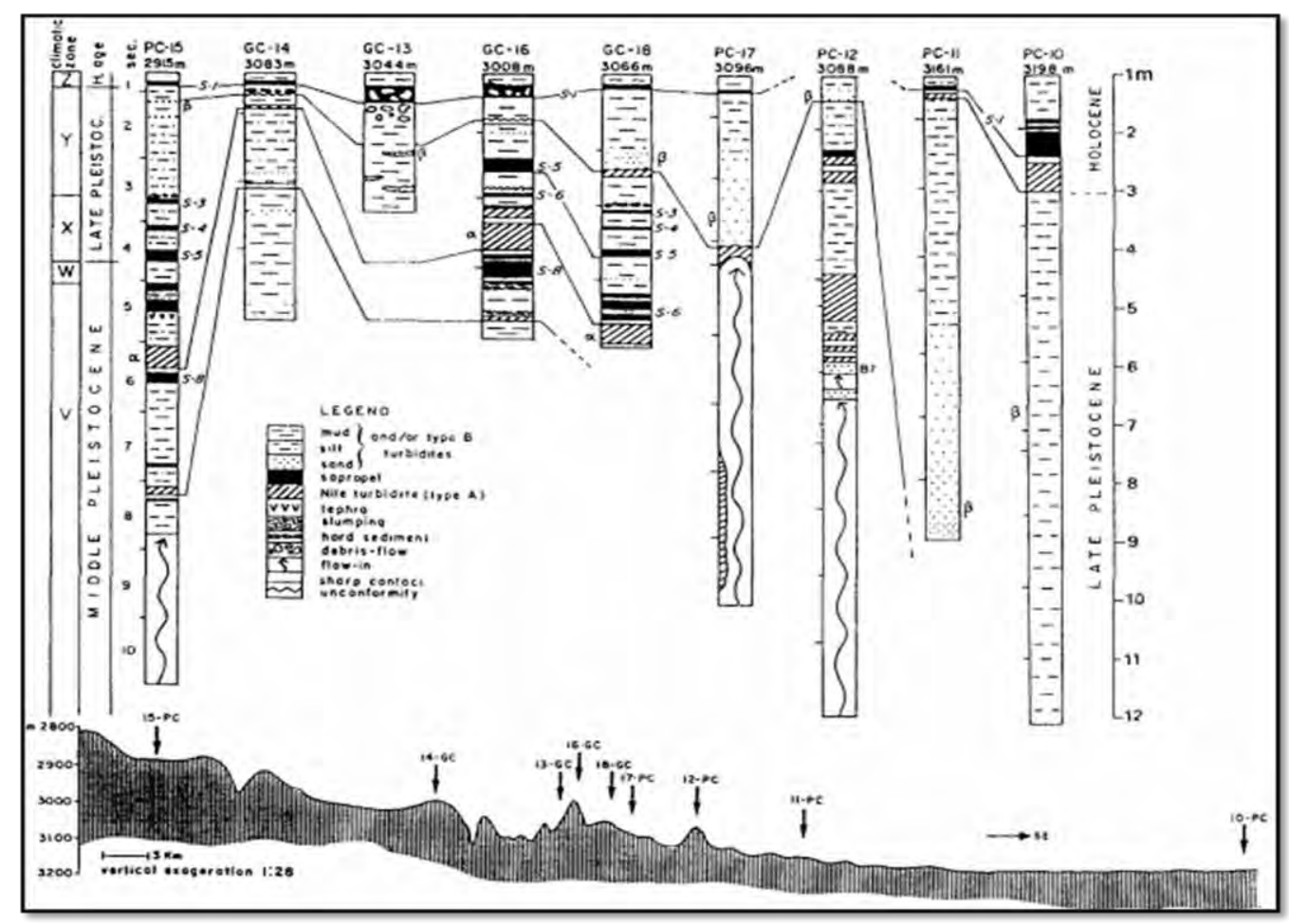

XLVII, No $3-1973$ 
Figure 3 - Stratigraphic columns of type A and B turbitides of 9 cores that were taken in the Herodotus basin. Also in black colour are shown the layers of sapropel (Cita et al., 1984).

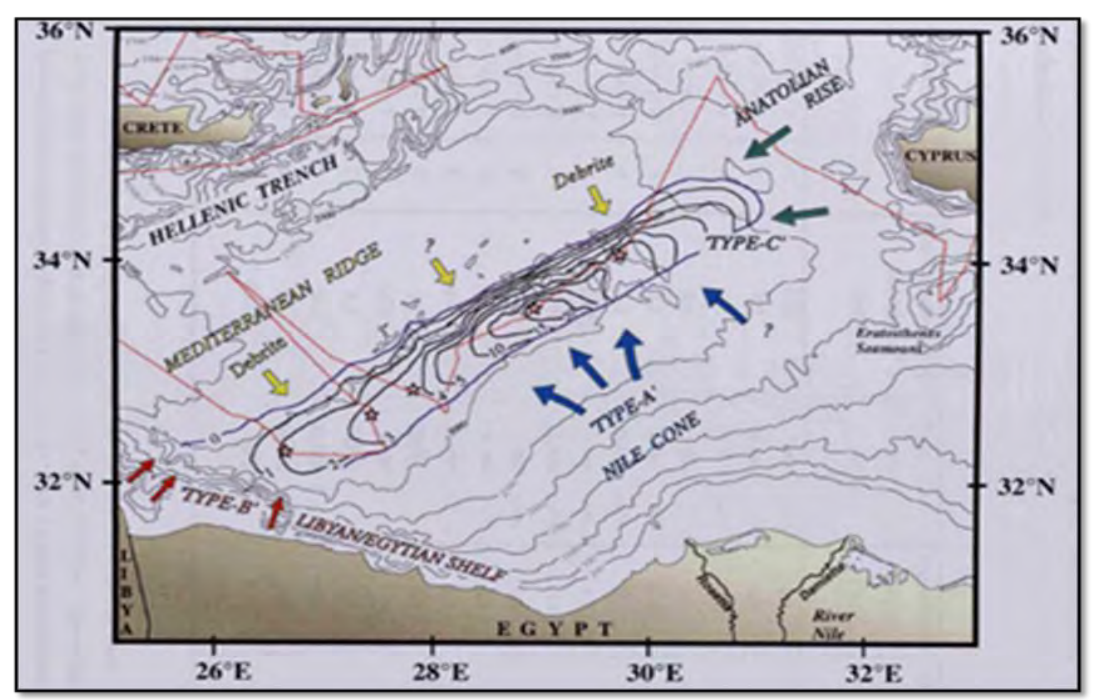

Figure 4 - Bathymetric map that shows the four turbitides sources in the Herodotus basin (Reeder et al., 2000).

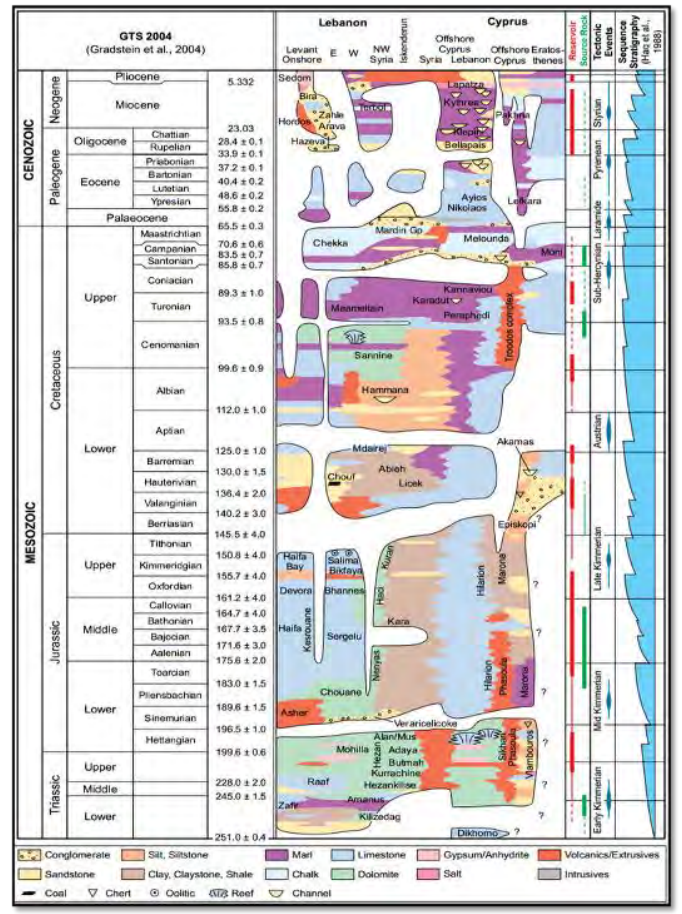

Figure 5 - Levantine basin stratigraphy (Roberts \& Peace 2007).

\section{Hydrocarbon Plays in Levantine Basin}

The source rocks (Figure 6) in the Levantine basin are Pliocene clays and are the source of dry biogenic gas. The source rocks that have the potential to give natural gas are the fine coarse 
sediments of Triassic and Jurassic age (Nader \& Swennen, 2004). In contrast, the source rocks that have the potential to give oil are sediments of Upper Cretaceous age

Potential reservoirs (Figure 6) are sandstones of Plio - Pleistocene, endo - Messinian, Oligocene, Eocene and Paleocene age. Sandstones and limestones of Cretaceous, including carbonate reefs. Sandstones, limestones, dolomites and oolitics limestones are the reservoirs of the Jurassic. Finally the oldest reservoirs are the Triassic sandstones.

The cap rocks (Figure 6) are the Messinian evaporites, Paleogene, Neogene and Cretaceous clays and marls and finally Triassic and Jurassic evaporates.

The migrations is through faults that exist in the basin (Figure 6). The traps are stratigraphic and structural such as anticline and pinch outs.

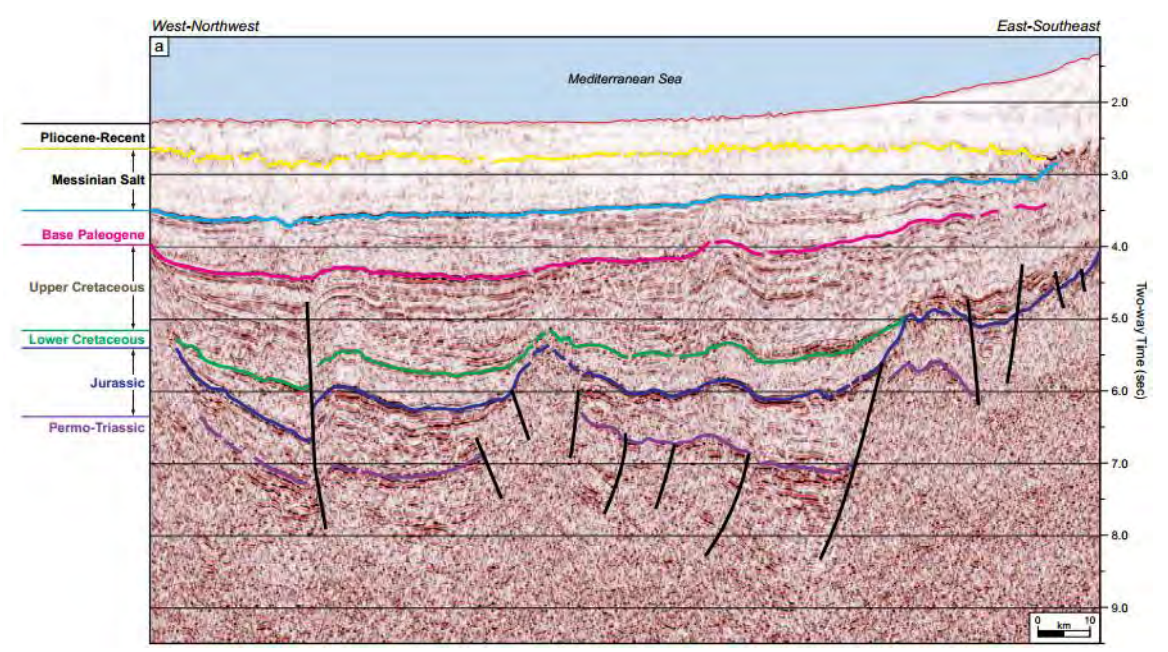

Figure 6 - WNW-ESE seismic line over the southern part of the Levantine Basin showing a Triassic-Jurassic rifted terrain and the age of the sequences. Section width approximately 160 km (Roberts \& Peace 2007).

\section{Direct Hydrocarbons Indicators (DHIs)}

\subsection{Seismic Flat Spot}

A seismic flat spot (Figure 7) may be a reflection from a well-defined fluid contact, commonly the gas/oil or gas/water contacts. The acoustic impedance contrast between the two phases may be sufficiently large to produce a strong reflection. In a section with dipping reflections, it stands-out because of its flat attitude. This is usually taken to be the most definitive and inJormative of all the Direct Hydrocarbon Indicators (Sheriff, 1995).

\subsection{Seismic Bright Spot}

A seismic bright spot (Figure 7) is a strong-amplitude reflection caused by large changes in acoustic impedance and tuning effects. In general, bright spots are mostly caused by lateral changes in lithotogy rather than DHIs. Nevertheless bright spot DHIs can also be due to a gassaturated sandstone reservoir underlying a shale interval. When seismic bright spots are on top of a structural high they are often associated with gas accumulation. Gas-induced bright spots usually have negative polarity for the reflection from the top of the reservoir (Semb 2009). 


\subsection{Seismic Gas Chimneys and Velocity Pushdown}

A gas chimney (Figure 7) describes the effects of escaped gas that is dispersed upwards in the sediments as imaged in the seismic data. The presence of the gas causes the seismic reflections to abruptly become dim or altogether disappear in the zone. The reduction of velocity through a hydrocarbon accumulation will also affect reflections from deeper intervals by increasing the twoway times. This is because the accumulation has a lower seismic velocity that causes the reflections to sag (Sheriff, 1995, Semb 2009).
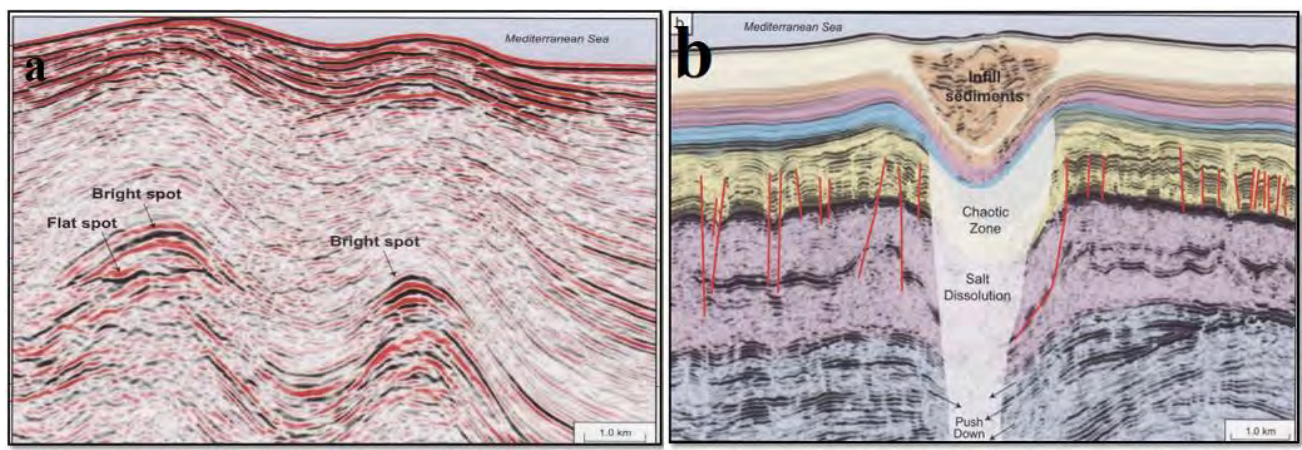

Figure 7 - Seismic sections showing a)flat spot, bright spot, b)recent sediments filling zone, dissolution of the salt and the deepest portion may represent gas chimney and pushdown zone (Semb 2009).

\subsection{Seismic Dim Spot}

By contrast to a bright spot, a seismic dim spot shows weak rather than strong amplitudes. The weak amplitude can correlate to the presence of hydrocarbons that reduce the contrast in acoustic impedance (AI) beiween the reservoir and the overlying rock. Such dim spots are often associated with the occurrence of oil or gas (Semb 2009).

\subsection{Seismic Shadow Zones}

A lowering of the seismic instantaneous frequency is often observed immediately beneath hydrocarbon accumulations. Such low-frequency seismic shadows (Figure 8) seem to be confined to a couple of cycles below accumulations. One anonymous reviewer invoked attenuation of the higher frequencies through the hydrocarbon zone as an explanation for this phenomenon; in particular for gas this effect can be quite large. The second anonymous reviewer further suggested that the removal of higher frequencies may be due in part to improper stacking with erroneous velocity assumptions or ray-path distortions (Semb 2009).
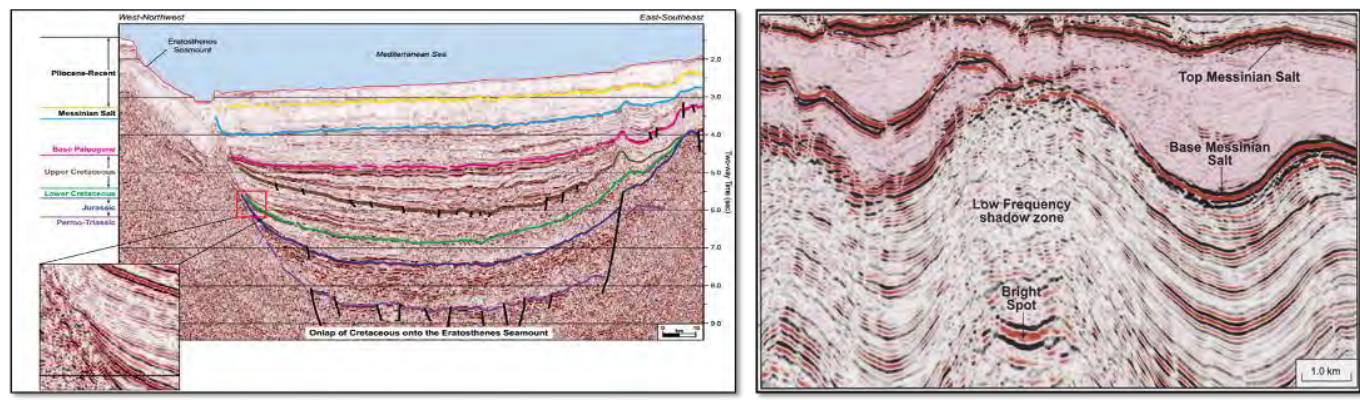

Figure 8 - WNW-ESE seismic line over the central part of the Levantine Basin shows pinchouts on the east Eratosthenes slopes (right image) (Roberts \& Peace 2007). Seismic section showing a shadow zone (Semb 2009).

$\underline{\text { XLVII, No } 3 \text { - } 1976}$ 


\subsection{Pinch-outs}

The pinch - outs (Figure 8) is when a porous reservoir rock lies between two layers of impermeable rock, such as clay layer or evaporites and the thickness is reduced to form a wedge which can be trap hydrocarbons.

\section{Genesis Conditions and Hydrocarbon Fields in Herodotus Basin Compared with Levantine Basin}

The source rocks in Herodotus basin for natural gas, are Pleistocene siltstones and sapropels, sapropel of Upper Miocene, Lower-Middle Miocene calcareous siltstones and fine coarse sediments of Upper Jurassic and Lower Cretaceous. For oil the source rocks are fine coarse sediments of Upper Cretaceous-Lower Cenozoic (Table 1).

Table 1: Comparative table of the two basins.

\begin{tabular}{|c|c|c|}
\hline CHARACTERISTICS & LEVANTINE BASIN & HERODOTUS BASIN \\
\hline AGE OF SEPARATION & Cretaceous & Cretaceous \\
\hline $\begin{array}{c}\text { AGE OF } \\
\text { DEVELOPMENT }\end{array}$ & MIDDLE MIOCENE & MIDDLE MIOCENE \\
\hline LENGTH & 325 KM AVERAGE & 450 KM AVERAGE \\
\hline WIDTH & 〜155 KM AVERAGE & 255 KM AVERAGE \\
\hline WATER DEPTH & $>2 \mathrm{KM}$ & $>3 \mathrm{KM}$ \\
\hline EXTEND & $\sim 50.375 \mathrm{KM}^{2}$ & $\sim 113.000 . \mathrm{KM}^{2}$ \\
\hline SEDIMENT THIKNESS & $10-14 \mathrm{KM}$ & $12-15 \mathrm{KM}$ \\
\hline SOURCE ROCKS & $\begin{array}{l}\text { PLIOCENE CLAYS, CRETACEOUS CLAYS, } \\
\text { FINE CARBONATES AND MARLS, } \\
\text { JURASSIC AND TRIASSIC CLAYS AND } \\
\text { SILTSTONES }\end{array}$ & $\begin{array}{l}\text { PLEISTOCENE SILTSTONES AND SAPROPELS, } \\
\text { MIOCENE SAPROPELS AND CALCAREOUS } \\
\text { SILTSTONES, U.JURASSIC-L.CRETACEOUS } \\
\text { FINE SEDIMENTS }\end{array}$ \\
\hline $\begin{array}{l}\text { POTENTIAL } \\
\text { RESERVOIRS }\end{array}$ & $\begin{array}{l}\text { PLIO-PLEISTOCENE, MESSINIAN, } \\
\text { TERTIARY SANDSTONES, CRETACEOUS } \\
\text { SANDSTONES, LIMESTONES AND } \\
\text { CARBONATE REEFS, JURASSIC } \\
\text { SANDSTONES, LIMESTONES, DOLOMITES } \\
\text { AND OOLITIC LIMESTONES, TRIASSIC } \\
\text { SANDSTONES }\end{array}$ & $\begin{array}{l}\text { TURBITIDE SANDS AND SAND FORMATIONS } \\
\text { RICH IN CARBONATE MATERIAL OF } \\
\text { PLEISTOCENE, BIOMICRITES, BIOARENITES, } \\
\text { FOSSILIFEROUS MICRITES AND } \\
\text { CALCARENITES OF MIOCENE, POROUS } \\
\text { SEDIMENTS OF JURASSIC AND CRETACEOUS }\end{array}$ \\
\hline SEAL ROCKS & $\begin{array}{l}\text { MESSINIAN EVAPORITES, TRIASSIC, } \\
\text { JURASSIC AND CRETACEOUS CLAYS AND } \\
\text { MARLS, TRIASSIC AND JURASSIC } \\
\text { EVAPORITES } \\
\end{array}$ & $\begin{array}{l}\text { MESSINIAN } \text { EVAPORITES, CALCAREOUS } \\
\text { SILTSTONES LOWER-MIDDLE MIOCENE AND } \\
\text { SILTSTONES OF PLEISTOCENE }\end{array}$ \\
\hline TRAPS & $\begin{array}{l}\text { STRUCTURAL AND STRATIGRAPHIC } \\
\text { (ANTICLINES, PINCH-OUTS, } \\
\text { UNCONFORMITIES) } \\
\end{array}$ & $\begin{array}{c}\text { STRUCTURAL AND STRATIGRAPHIC } \\
\text { (ANTICLINES, PINCH-OUTS, UNCONFORMITIES) }\end{array}$ \\
\hline MIGRATION & FAULTS & FAULTS \\
\hline OIL (BBL) & 1.68 & $\geq 1.68$ \\
\hline NATURAL GAS (TCF) & 122 & $\geq 122$ \\
\hline
\end{tabular}


Potential reservoirs are turbitide sands and sand formations rich in carbonate material of Pleistocene age, biomicrites, bioarenites, fossiliferous micrites and calcarenites of Miocene age, and finally porous sediments of Jurassic and Cretaceous age.

The cap rocks are the Messinian evaporites, Lower-Middle Miocene calcareous siltstones and siltstones of Pleistocene age.

The migrations are through faults that exist in the basin. The traps are stratigraphic and structural such as anticline and pinch outs.

\section{Conclusions}

In conclusion, as shown in Table 1, the two basins formed at the same age (Upper Cretaceous), and developed as foreland basins during middle Miocene. They have the same evolution story and host the same types of sediments with approximately the same thickness. However the Herodotus basin seems to have twice the area of Levantine basin. The Levantine basin has certified reserves of natural gas (122 tcf) and oil (1.68 bbl). So, we can say that Herodotus basin contains at least the same amount of natural gas and oil as in the Levantine basin.

\section{References}

Bruneton A., Konofagos E. and Foscolos E. A. 2012. Cretan Gas Fields-A New Perspective For Greece's Hydrocarbon Resources.

Bruneton A., Konofagos E. and Foscolos E. A. 2012. The importance of Eastern Mediterranean gas fields for Greece and the EU.

Camerlenghi A. 1990. Anoxic Basins of the Eastern Mediterranean. Marine Chemistry, 31 1-19 1, Elsevier Science Publishers B,V., Amsterdam Geological Framework.

Cita M.B., Beghi C., Camerlenghi A., Kastens K.A., McCoy F.W., Nosetto A., Parisi E., Scolarp F. and Tomadin L. 1984. Turbidites And Megaturbidites From The Herodotus Abyssal Plain (Eastern Mediterranean) Unrelated To Seismic Events, Marine Geology, 55: 79-101.

Foscolos A. 2011.Geological and geochemical evidences indicating the existence of large hydrocarbon deposits in the Libyan sea within the Greek exclusive economic zone (EEZ).

Gardosh M., Druckman Y., Buchbinder B. and Rybakov M. 2006. The Levant Basin Offshore Israel: Stratigraphy, Structure, Tectonic Evolution and Implications for Hydrocarbon Exploration.

Gardosh M. and Druckman Y. 2006. Seismic Stratigraphy, Structure and Tectonic Evolution of the Levantine Basin, Offshore Israel. Geological Society, London, Special Publications, 260: 201-227.

Harrison W.R. 2008. A Model For The Plate Tectonic Evolution Of The Eastern Mediterranean Region That Emphasizes The Role Of Transform (Strike-Slip) Structures, $1^{\text {st }}$ WSEAS International Conference on ENVIRONMENTAL and GEOLOGICAL SCIENCE and ENGINEERING (EG'08) Malta, September 11-13.

Kempler D. 1998. Eratosthenes Seamount: The Possible Spearhead of Incipient Continental Collision in the Eastern Mediterranean, Proceedings of the Ocean Drilling Program, Scientific Results, Vol. 160.

Loncke L., Gaullier V., Mascle J., Vendeville B. and Camera L. 2006. The Nile Deep Sea Fan: An Example of Interacting Sedimentation, Salt Tectonics, and Inherited Subsalt Paleotopographic Features, Marine and Petroleum Geology, 23: 297-315.

Maldonado A. and Stanley J.D. 1976. The Nile Cone: Submarine Fan Development By Cyclic Sedimentation, Marine Geology, 20: 27-40.

Maravelis A., Manutsoglu E., Konstantopoulos P., Makrodimitras G., Zoumpouli E. and Zelilidis A. 2013. Hydrocarbon Plays and Prospectivity of the Mediterranean Ridge, Energy Sources, Part A: Recovery, Utilization, and Environmental Effects (in press).

XLVII, No $3-1978$ 
Mascle J., Zitter T., Bellaiche G., Droz L., Gaullier V. and Loncke L. Prismed Scientific Party, 2001. The Nile Deep Sea Fan: Preliminary Results From a Swath Bathymetry Survey, Marine and Petroleum Geology, 18: 471-477.

Montadert L., Nicolaides S., Semb H.P. and Lie O. 2009. Petroleum Systems Offshore Cyprus.

Netzeband L.G. Gohl K., Hubscher P. C., Ben-Avraham Z., Dehghani A. G., Gajewski D. and Liersch P., 2006. The Levantine Basin - Crustal Structure and Origin, Tectonophysics, 418: 167-188.

Netzeband L.G., Hubscher P.C. and Gajewski D. 2006. The Structural Evolution of the Messinian Evaporites in the Levantine Basin, Marine Geology, 230: 249-273.

Reeder S.M., Rothwell G.R. and Stow A.V.D. 2000. Influence Of Sea Level And Basin Physiography On Emplacement Of The Late Pleistocene Herodotus Basin Megaturbidite, SE Mediterranean Sea, Marine and Petroleum Geology, 17: 199-218.

Reeder S.M., Rothwell G.R., Stow A.V.D., Kahler G. and Kenyon H. N., 1998. Turbidite Flux, Architecture And Chemostratigraphy Of The Herodotus Basin, Levantine Sea, SE Mediterranean, Geological Society, London, Special Publications 129: 19-41.

Reeder S.M. 2000. Megaturbidites And The Late Quaternary Regional Sedimentology Of The Eastern And Central Mediterranean Sea, University of Southampton, Faculty of Science, School of Ocean and Earth Science, Doctoral Thesis, 381pp.

Roberts G. and Peace D. 2007. Hydrocarbon Plays and Prospectivity of the Levantine Basin, Offshore Lebanon and Syria From Modern Seismic Data, GeoArabia Vol. 12, No 3.

Robertson H.F.A., Kidd B.R., Ivanov K.M., Limonov F.A., Woodside M.J., Galindo-Zaldivar J., Nieto L. and the Scientific Party of the 1993 TTR-3 Cruise. Eratosthenes Seamount: Collisional Processes in the Easternmost Mediterranean in Relation to the Plio - Quaternary Uplift of Southern Cyprus. Terra Nova, 7: 255-264.

Rothwell R.G., Reeder M.S., Anastasakis G., Stow D.A.V., Thomson J. and Khaler G. 2000. Low Sea-Level Stand Emplacement Of Megaturbidites In The Western And Eastern Mediterranean Sea, Sedimentary Geology,135,(1/4):75-88.

Scalera G. 2006. The Mediterranean as a slowly nascent ocean.

Semb H.P. 2009. Possible Seismic Hydrocarbon Indicators in Offshore Cyprus and Lebanon, GeoArabia 14: 49-66.

Semb H.P. 2010. Offshore Cyprus and Lebanon, a Feature Hydrocarbon Player, $8^{\text {th }}$ Biennial International Conference \& Exposition on Petroleum Geophysics.

Smith G.S. 1976. Diapiric Structures In The Eastern Mediterranean Herodotus Basin, Earth and Planetary Science Letters, 32: 62-68.

Stanley J.D. 1973. Basin Plains In The Eastern Mediterranean: Significance In Interpreting Ancient Marine Deposits, Marine Geology, 15: 295-307 Herodotus Basin area Bullard Laboratories, Department of Earth Sciences.

Tanner J. S. 1983. A Detailed Survey In The Mediterranean Rise And Herodotus Basin Area, Geophjx. J. R. astr. SOC. 13: 173-195.

Tari G., Hussein H. and Novotny B. 2010. Play Types and Hydrocarbon Potential of Deep-Water NW Egypt.

Vidal N., Alvarez-Marron J. and Klaeschen D. 2000. Internal Configuration of the Levantine Basin From Seismic Reflection Data (Eastern Mediterranean), Earth and Planetary Science Letters 180: 77-89.

Voogd D. B., Truffert C., Chamot-Rooke N., Huchon P., Lallemant S. and Le Pichon X. 1992. Two-Ship Deep Seismic Soundings In The Basins Of The Eastern Mediterranean Sea (Pasiphae cruise), Geophys. J. Int., 109: 536-552. 